\title{
THE EFFECTS OF SELECTIVE CUTTING ON THE DOMINANCE AND THE RELATIVE DENSITY OF MANGROVE SPECIES IN THE COMPLEX OF THE GUAXINDIBA RIVER/ENGENHEIRO ANTONIO RESENDE CHANNEL, RIO DE JANEIRO
}

Recebido em: 20/01/2013

Aceito em: 20/02/2015

Gabriele Paiva CHAGAS $^{1}$

Carlos Eduardo REZENDE ${ }^{1}$

Elaine BERNINI ${ }^{2 *}$

\begin{abstract}
This study evaluated the effect of selective cutting on the dominance and the relative density of mangrove_species in the Complex of the Guaxindiba River/Engenheiro Antonio Resende Channel, in Rio de Janeiro State, Brazil. Ten plots were demarcated along the estuary and within each plot measurements were taken of the diameter at breast height $(\mathrm{DBH})$ for individuals $\geq 2.5 \mathrm{~cm}$. Measurements of selective cutting and regrowth were made for the different species. The cutting of vegetation was registered in 9 of the 10 plots analyzed and

varied from 2 to $43 \%$. 4 . There was no relation between the percent of trunks cut and the proximity of residential areas. Selective cutting was found for Avicennia germinans and Laguncularia racemosa, but only $L$. racemosa presented regrowth. The results suggest that $L$. racemosa is more highly affected by selective cutting when compared to the other species, though this impact did not modify the species dominance and the relative density in the mangrove analyzed due to the high regrowth of $L$. racemosa.
\end{abstract}

Keywords: mangrove, estuary, conservation, vegetation

\section{RESUMO}

Este estudo avaliou o efeito do corte seletivo na dominância e densidade relativa das espécies de mangue no Complexo Rio Guaxindiba/Canal Engenheiro Antonio Resende, Rio de Janeiro, Brasil. Dez parcelas foram demarcadas ao longo do estuário e dentro de cada parcela foram medidas a altura e o diâmetro à altura do peito (DAP) dos indivíduos $\geq 2,5 \mathrm{~cm}$. O registro de corte seletivo e rebrotamento foram feitos por espécie. O corte de vegetação foi registrado em 9 das 10 parcelas analisadas e variou de 2 a 43\%. Não houve relação entre o percentual de troncos cortados e a proximidade da área residencial. Verificou-se corte seletivo para Avicennia germinans e Laguncularia racemosa, mas apenas $L$. racemosa apresentou rebrotamento. Os resultados sugerem que $L$. racemosa é mais afetada pelo corte seletivo em relação às demais espécies, mas este impacto não modificou a dominância e a densidade relativa das espécies no manguezal analisado, em função da boa regeneração de L. racemosa.

Palavras chave: manguezal, estuário, conservação, vegetação

\section{INTRODUCTION}

Mangroves are coastal ecosystems that occupy approximately $137,760 \mathrm{~km}^{2}$, which corresponds to $0.7 \%$ of the total tropical forests of the world (Giri et al. 2011). Like other tropical terrestrial forests, mangrove forests have been exploited for centuries, and the decline of mangrove areas has reached alarming rates over the last few decades (Valiela et al. 2001). The loss of mangrove areas is caused by natural or anthropogenic agents, and frequently by both simultaneously. Impacts of anthropogenic origin can occur on a large scale, as with shrimp

1 - Laboratório de Ciências Ambientais, Centro de Biociências e Biotecnologia, Universidade Estadual do Norte Fluminense. Av. Alberto Lamego 2000, Parque Califórnia, CEP: 28.013-602, Campos dos Goytacazes, Rio de Janeiro, Brasil.

2 - Departamento de Engenharia e Meio Ambiente, Universidade Federal da Paraíba, Campus IV - Rio Tinto. Rua da Mangueira, s/n, Centro - Companhia de Tecidos Rio Tinto, CEP 58297-000, Rio Tinto, Paraíba, Brasil.

Authors e-mails: gp_chagas@ hotmail.com; crezende@uenf.br; *Corresponding author: elainebernini@ hotmail.com 
CHAGAS, G. P.; REZENDE, C. E.; BERNINI, E. The effects of selective cutting on the dominance and the relative density of mangrove species in the Complex of the Guaxindiba River/Engenheiro Antonio Resende Channel, Rio de Janeiro.

farming and infrastructure construction, or on a small scale, as with the release of sewage, channel construction, and selective logging (Cintrón-Molero e Schaeffer-Novelli, 1992; Alongi, 2002).

In general, the logging of vegetation on a small scale is cited as one of the anthropogenic effects that affects mangrove forests (Silva et al. 2005, Berger et al. 2006, Walters et al. 2008, Bernini; Rezende. 2010, 2011). However, some studies have evaluated the effect of logging/cutting on the structure and the composition of the forests (Eusébio et al., 1986, Ewel et al., 1998, Souza e Sampaio 2001, Pinzón et al., 2003, Walters 2005, Alongi; Carvalho 2008, Queiroz 2009). The impact of selective cutting on species composition has not been the subject of many studies to date, especially in mangrove areas. Those that have been performed suggest that selective cutting may result in changes in abundance, since some species may be affected more than others by cutting (EUZÉBIO et al. 1986, PINZÓN et al. 2003). Nevertheless, some studies have demonstrated no or little alteration in the species composition as a result of selective logging/cutting due to natural regeneration (EWEL et al. 1998, WALTERS, 2005). In Brazil, there are no studies to date that have evaluated the effect of selective cutting on the species composition of mangrove forests.

The mangrove forests in the state of Rio de Janeiro, Brazil are composed of the species Avicennia germinans (L.) Stearn, Avicennia schaueriana Stapf \& Leechm. ex Moldenke, Laguncularia racemosa (L.) Gaertn. f., and Rhizophora mangle L., and are affected by various types of impact, such as earthworks, alterations in drainage patterns, dredging projects, cutting of vegetation, industrial and domestic effluent discharge, and oil spills (SILVA et al. 1991, SOARES, 1999, BERNINI; REZENDE 2004, Oliveira 2007, BERNINI; Rezende 2010). The mangrove of the Complex of the Guaxindiba River/Engenheiro Antonio Resende Channel is located within the municipality of São Francisco de Itabapoana, state of Rio de Janeiro, Brazil and is distributed over approximately $0.11 \mathrm{~km}^{2}$. The mangrove forests of both sides of the river have suffered different types of human impact, most notably the discharge of sewage, embankments for the construction of residences, and the cutting of vegetation.

In this context, the objective of this study is to evaluate the effects of selective cutting on the dominance and relative density of species of the mangrove forest of the Complex of the Guaxindiba River/Engenheiro Antonio Resende Channel, with the specific goal of verifying the degree to which certain species are undergoing differential impact.

\section{STUDY AREA}

The Guaxindiba River basin comprises an area of approximately $1,111 \mathrm{~km}^{2}$ and is located within the municipalities of São Francisco de Itabapoana and Campos dos Goytacazes, Rio de Janeiro State (Fig. 1; IBGE 2008). The region's climate is hot and humid with summer rains. The annual precipitation varies between 1,000 and $1,250 \mathrm{~mm}$, and temperature ranges between $18^{\circ}$ to $24^{\circ}-\mathrm{C}$ (DNAEE 1993 ).

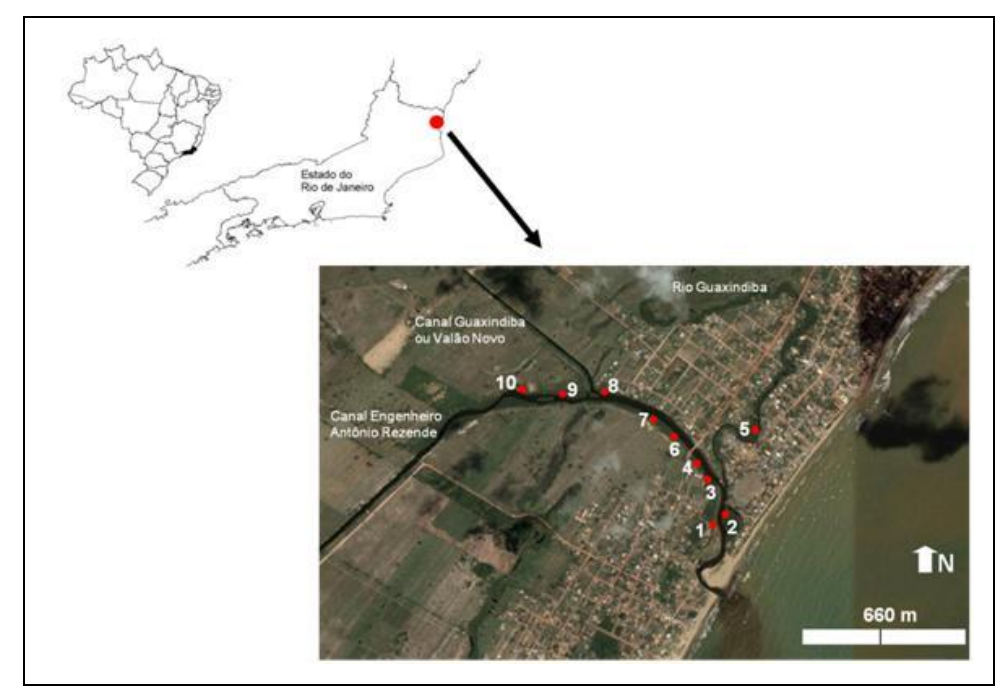


CHAGAS, G. P.; REZENDE, C. E.; BERNINI, E. The effects of selective cutting on the dominance and the relative density of mangrove species in the Complex of the Guaxindiba River/Engenheiro Antonio Resende Channel, Rio de Janeiro.

Figura 1 - Location of study sites in the Complex of the Guaxindiba River/Engenheiro Antonio Resende Channel, Rio de Janeiro, Brazil. Source: Google Earth.

The Guaxindiba River begins in the District of Morro do Coco, Campos dos Goytacazes, and initially is called the Grande stream. Further downriver this stream receives the names Guaxindiba stream and Guaxindiba River. Its mouth is located in the District of Guaxindiba, São Francisco de Itabapoana, state of Rio de Janeiro. Two channels were constructed during the 1970 s at the mouth of the Guaxindiba River: the Engenheiro Antonio Resende and the Guaxindiba Channels (Fig. 1), both of which are affected by ocean waters (SOFFIATI, 2001). The construction of these channels helped expand the mangroves. Along the banks of the Engenheiro Antonio Resende Channel the mangrove vegetation became established in thin bands ( 5 to $15 \mathrm{~m}$ ) adjacent to the water. In the Guaxindiba channel, the mangrove plants are distributed randomly, intermingling with vegetation more typical of restingas and pastures (grasses). In 1973 the state road RJ-196 was constructed, blocking the flow of the Guaxindiba River and affecting the mangrove as a result of the reduced water supply the mangrove (SOFFIATI, 2001).

\section{MATERIAL AND METHODS}

The present study was carried out between January 2010 and December 2010. The structural characterization of the mangrove was based on the methodology proposed by Cintron and Schaeffer--Novelli (1984). Nine sites that were representative of the larger mangrove area were selected along the Engenheiro Antonio Resende Channel (Fig. 1). On the Guaxindiba River, only one site was selected due to the thin band of mangrove present there as well as the elevated levels of sewage in the area that posed health risks to the researchers. No sites were selected in the Guaxindiba Channel because no forests were present there.

Plots of $10 \times 5 \mathrm{~m}$ were demarcated at each site. Within each plot plants were identified by species and the DBH (diameter at breast height, $1.30 \mathrm{~m}$ from the substrate) of all individuals with a diameter $\geq 2.5 \mathrm{~cm}$ were measured. A calibrated instrument was employed to measure the DBH in $n$ units directly from the diameter. When the main trunks or a main branch had been cut, these occurrences were measured (Walters 2005). Regrowth (emergence of branches close to where the cutting was done) were also recorded.

Dominance and relative density of species were calculated in accordance with Cintron e Schaeffer-Novelli (1984). The distribution of trunks per diameter class was performed by species. Relative density of species data were utilized in the grouping analysis (UPGMA) performed with the program Statistic 8.0.

\section{RESULTS}

This study registered the presence of the species Avicennia germinans (L.) Stearn., Avicennia schaueriana Stapf \& Leechm ex Moldenke, Laguncularia racemosa (L.) Gaertn. f., and Rhizophora mangle L., as well as the associated species Acrostichum aureum L., Hibiscus pernambucensis Arruda, and Dalbergia sp.

The percentage of cut trunks varied from 1.8 to $42.9 \%$ and was higher in sites $1,8,2$, and 9 , respectively (tab. 1 ). This type of impact was not found in site 3 . There were no registers of cut trunks for Avicennia schaueriana or $R$. mangle. Laguncularia racemosa presented cut trunks in $80 \%$ of the sites analyzed, with the highest values in sites 1,8 , and 2 , respectively (tab. 1). With respect to $A$. germinans, cut trunks were found in sites 2,8 , and 9 , with the highest percent in site 8 . Regrowth was found only with Laguncularia racemosa in sites 1, 2, 5, 6, 7, and 10 (tab. 1).

Laguncularia racemosa presented the highest dominance (Figure $2 \mathrm{~A}$ ) and relative density (Figure $2 \mathrm{~B}$ ) in relation to the other species in sites 1 to 7 . Site 8 presented a co-dominance of A. germinans and Laguncularia racemosa. In sites 9 and 10 A. germinans was the species with the highest dominance values and relative density. Avicennia schaueriana was only registered in site 1, with low dominance and relative density values (Fig. 2). Rhizophora mangle also presented low dominance and relative density and was registered in sites 2, 7, and 10 (Fig. 2). 
CHAGAS, G. P.; REZENDE, C. E.; BERNINI, E. The effects of selective cutting on the dominance and the relative density of mangrove species in the Complex of the Guaxindiba River/Engenheiro Antonio Resende Channel, Rio de Janeiro.

The distribution of trunks by diameter class demonstrated that $A$. germinans generally presented the highest contribution of trunks in the diameter classes $<11.5 \mathrm{~cm}$ (Fig. 3). This species exhibited a low number of trunks with diameters $>14.5 \mathrm{~cm}$. Laguncularia racemosa exhibited a distribution with higher number of trunks in the lowest diameter classes for the majority of sites analyzed (Figure 3). In site 2 this species presented a lower number of trunks in the 5.6-8.5 cm class when compared with the 2.5-5.5 and 8.6-11.5 cm classes (Fig. 3B). In site 8, however, Laguncularia racemosa exhibited the highest number of trunks in the 8.6-11.5 $\mathrm{cm}$ class compared with the lower classes (Fig. 3H). With regard to Avicennia schaueriana and $R$. mangle it was not possible to verify a distribution pattern due to the low number of trunks (Fig. 3).

The grouping analysis based on the relative density separated the sites into two large groups (Fig. 4). The largest group is composed of the sites 1, 3, 4, 5, 6, and 7, with the higher relative density of Laguncularia racemosa (Fig. 2B). The second group is formed by two subgroups. The first subgroup (sites 9 and 10) presents the highest relative density of $A$. germinans (Fig. 2B). The second subgroup (sites 2 and 8 ) exhibits the highest relative density of Laguncularia racemosa, though with a higher relative density of $A$. germinans in relation to the first major group (Fig. 2).

Table 1. Total percentage of cut trunks and cutting and coppicing percentage by species in the Complex of the Guaxindiba River/Engenheiro Antonio Resende Channel, Rio de Janeiro, Brazil. Values in parentheses represent the sum of the live and dead trunk numbers sampled and the number of regrowths registered in cut trunks. There was no record of cutting and/or regrowth for Avicennia schaueriana and Rhizophora mangle.

\begin{tabular}{l|c|c|c|c|c}
\hline \multirow{2}{*}{ Site } & \multirow{2}{*}{$\begin{array}{c}\text { Total of Cut } \\
\text { Trunks }\end{array}$} & \multicolumn{2}{|c|}{ Avicennia germinans } & \multicolumn{2}{c}{ Laguncularia racemosa } \\
\cline { 3 - 6 } & Cut (\%) & $\begin{array}{c}\text { Regrowth } \\
(\%)\end{array}$ & $\begin{array}{c}\text { Cut } \\
(\%)\end{array}$ & $\begin{array}{c}\text { Regrowth } \\
(\%)\end{array}$ \\
\hline S1 & $42.9(87)$ & 0 & 0 & $30.8(87)$ & $9.0(87)$ \\
\hline S2 & $29.1(73)$ & $0.9(73)$ & 0 & $13.6(73)$ & $1.8(73)$ \\
\hline S3 & $(103)$ & 0 & 0 & 0 & 0 \\
\hline S4 & $2.4(42)$ & 0 & 0 & $1.5(42)$ & 0 \\
\hline S5 & $6.6(67)$ & 0 & 0 & $4.9(67)$ & $2.5(67)$ \\
\hline S6 & $5.3(41)$ & 0 & 0 & $2.1(41)$ & $1.1(41)$ \\
\hline S7 & $1.8(60)$ & 0 & 0 & $1.6(60)$ & $3.1(60)$ \\
\hline S8 & $33.3(24)$ & $14.3(24)$ & 0 & $14.3(24)$ & 0 \\
\hline S9 & $11.1(28)$ & $3.0(28)$ & 0 & 0 & 0 \\
\hline S10 & $3.2(34)$ & 0 & 0 & $1.5(34)$ & $3.0(34)$ \\
\hline
\end{tabular}


CHAGAS, G. P.; REZENDE, C. E.; BERNINI, E. The effects of selective cutting on the dominance and the relative density of mangrove species in the Complex of the Guaxindiba River/Engenheiro Antonio Resende Channel, Rio de Janeiro.

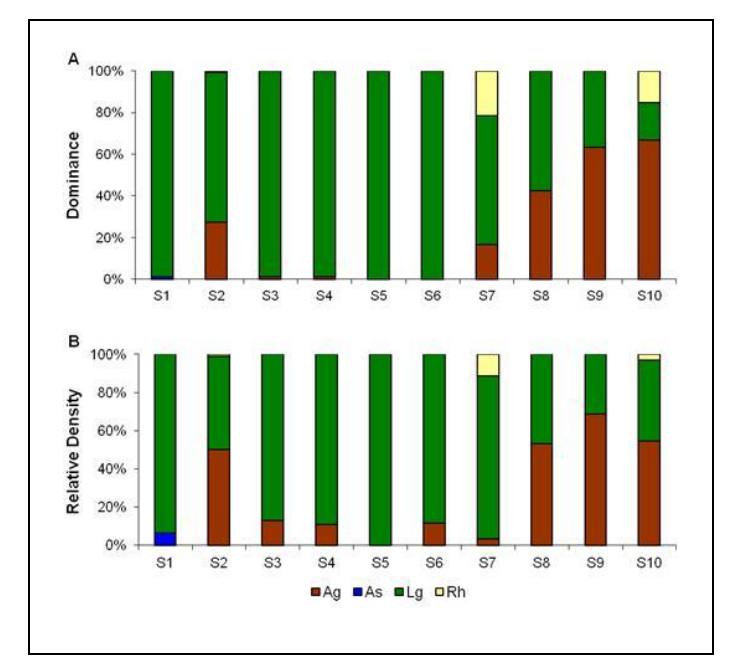

Figure 2 - (A) Dominance of trunks by species and (B) relative density of trunks by species in the Complex of the Guaxindiba River/Engenheiro Antonio Resende Channel, Rio de Janeiro, Brazil. Ag: Avicennia germinans; As: Avicennia schaueriana; Lg: Laguncularia racemosa; Rh: Rhizophora mangle.

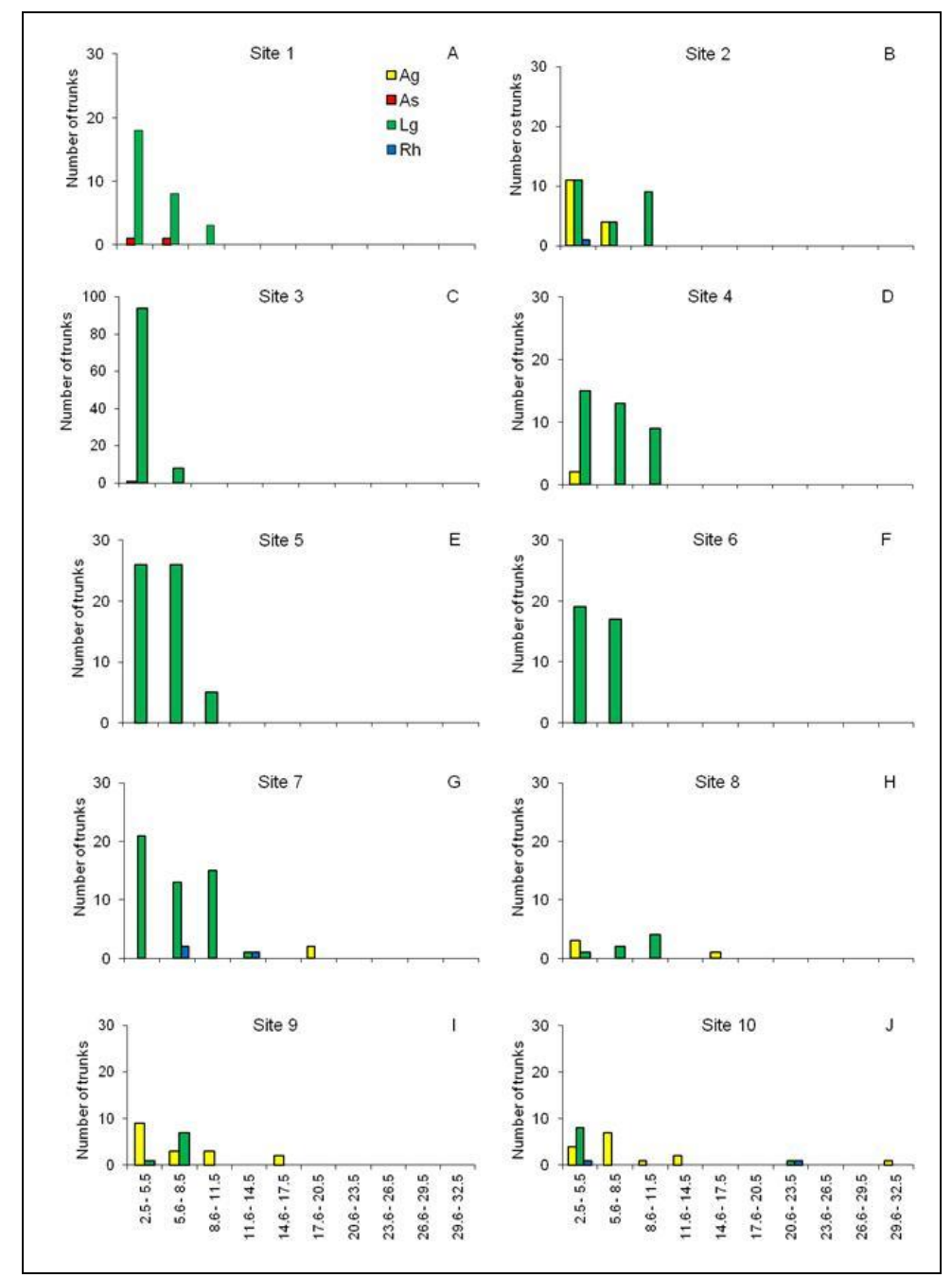

Figure 3 - Distribution of live trunks by diameter class (x axis, in $\mathrm{cm}$ ), in the Complex of the Guaxindiba River/Engenheiro Antonio Resende Channel, Rio de Janeiro, Brazil. (A) Ag: Avicennia germinans; As: Avicennia schaueriana; Rh: Rhizophora mangle. (B) Lg: Laguncularia racemosa. 
CHAGAS, G. P.; REZENDE, C. E.; BERNINI, E. The effects of selective cutting on the dominance and the relative density of mangrove species in the Complex of the Guaxindiba River/Engenheiro Antonio Resende Channel, Rio de Janeiro.

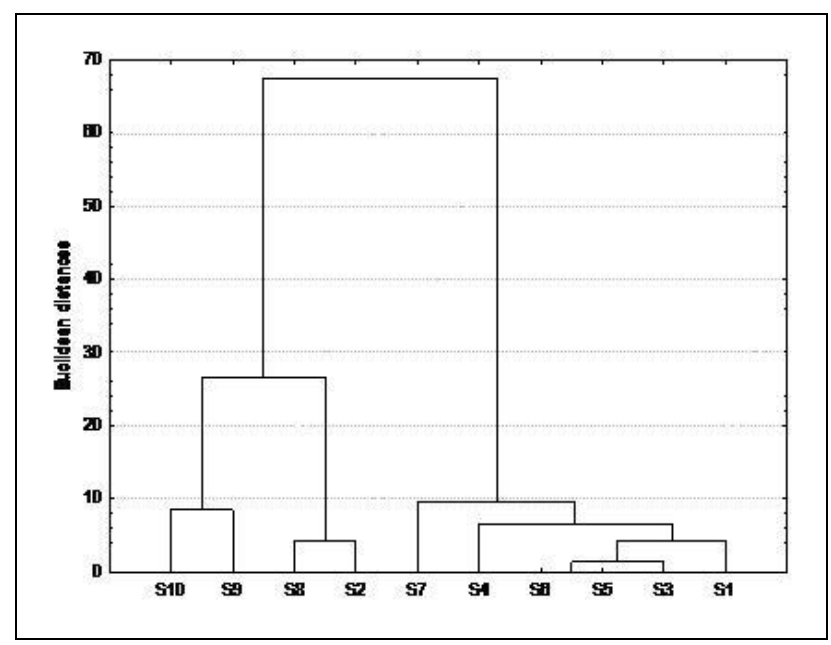

Figure 4 - Cluster analysis (UPGMA) performed for the data for relative density of the species on the sites considered in the Complex of the Guaxindiba River/Engenheiro Antonio Resende Channel, Rio de Janeiro, Brazil. S: site.

\section{DISCUSSION}

Studies have demonstrated that the cutting of vegetation can cause alterations in the structure of mangrove forests. For example, Walters (2005), reported that mangrove forests subjected to this impact were characterized by lower tree height and basal area values and higher numbers of clearings in Philippine mangroves. Souza \& Sampaio (2001), registered trees with reduced size and contribution of individuals in classes of higher diameters in mangroves subjected to cutting in Suape, Pernambuco, Brazil. Accordingly, forest submitted to the constant removal of wood in mangroves of the Barra de Mamanguape, Paraíba, Brazil exhibited reduced height and density values (PALUDO; KLONOWSKI, 1999).

In our study we chose not to assess the effect of selective cutting in the structural parameters (height and diameter) due to different age forests and because it would be an appropriate long-term monitoring. The forests have different ages due to the changes caused to the course of the Guaxindiba River as a result of the establishment of the Engenheiro Antônio Rezende Channel in the 1970s. After this intervention ${ }_{\star}$ new mangrove forests developed which may thus be up to 40 years old (sites $4,6,7,8,9$, and 10). Sites 1, 2, and 3, however, are composed of younger forest that has been in existence approximately 7 to 16 years, according to information provided by local residents. Nevertheless, it is possible to verify the effect of selective cutting on dominance and relative density of species of the studied area.

The percentages of trunks cut ( 2 to $43 \%$ ) were lower to the values registered by Alongi and Carvalho (2008) (30-50\%) and Walters (2005) (13-72\%). The results indicate that Laguncularia racemosa is more affected by selective cutting than the other species. This may be related to the fact that this species is the most abundant and/or because its wood presents those characteristics that are most sought after for use in the region. The percentage of cut trunks for $A$. germinans was in fact inferior despite the fact that this species presented higher structural development (increased diameter). This species, however, exhibited low numbers of individuals. Cut trunks are chiefly used as fenceposts, for the building of houses, and in the construction of elevated walkways used by fishermen to gain access to their boats. According to information provided by local residents, the trunks of Laguncularia racemosa are prized for being straighter and more appropriate for these different uses.

Laguncularia racemosa exhibited higher dominance and relative density in the sites that were closer to the ocean, while $A$. germinans was dominant and had higher relative density in the sites more strongly influenced by fresh-water. A similar distribution was reported for the Itabapoana River mangrove (BERNINI, REZENDE 2010), located approximately $23 \mathrm{~km}$ from the Guaxindiba River. Laguncularia racemosa is typical of degraded mangrove forests in a stage of regeneration and is considered a pioneer species in succession (TOMLINSON, 1986, SOARES 1999, SOUZA \& SAMPAIO, 2001, BERNINI \& REZENDE 2010), as observed in the present study. 
CHAGAS, G. P.; REZENDE, C. E.; BERNINI, E. The effects of selective cutting on the dominance and the relative density of mangrove species in the Complex of the Guaxindiba River/Engenheiro Antonio Resende Channel, Rio de Janeiro.

The distribution of trunks by diameter class in sites 2 and 8 demonstrated a reduced presence of trunks of less than $8.6 \mathrm{~cm}$, suggesting that this size bracket is the one most made use of by the local population. In fact, low numbers of large trees exist in the mangroves analyzed. Local residents, however, avoid cutting trunks in very young forests of Laguncularia racemosa, as is the case in site 3 . There was no relation between the percentage of cut trunks and proximity of residential areas, as the selective cutting occurred in almost all the sites. This is due to the thin tract of the forest and the easy access it offers to the population.

Though the selective cutting didn't alter the species composition, there is evidence in the forest analyzed in site 2 that this may occur in the future, for the selective cutting is a recurrent problem. According to the results of dominance, relative density, and trunks cut higher percentages of Laguncularia racemosa trunks would be expected in site 2 . This result, however, went unfound due to the selective cutting there ${ }_{+}$that reduced the number of trunks of this species. Were it not for the selective cutting of Laguncularia racemosa, site 2 would have joined the ranks of the other groups with higher relative density, according to the grouping analysis. There was no alteration of dominance or relative density of species in this site due to the higher regrowth percentage of Laguncularia racemosa compared with $A$. germinans, which presented no regrowth. Thus compensation occurred as a result of the high regeneration rate of Laguncularia racemosa. Nonetheless, this study only examined vegetative regeneration data, and more studies are needed in order to verify the reproductive regeneration potential of the species.

Similarly, Walters (2005), reported that Rhizophora mucronata was more negatively affected by cutting in relation to the other species, yet concluded that there was little evidence that selective cutting had altered the composition, because the impact is compensated by the high regeneration of this species. In their analysis of mangroves in Micronesia, Ewel et al. (1998) also found no evidence of changes in composition due to the selective cutting of Rhizophora apiculata and Bruguiera gymnorhiza, citing compensation related to the regeneration of these species. In other mangrove forests of Micronesia, however, Pinzón et al. (2003) found that Rhizophora apiculata exhibited lower abundance than Bruguiera gymnorhiza in forests subjected to cutting and in mangroves of the Philippines, Eusébio et al. (1986) demonstrated that because it was cut more intensely and because its regeneration was slower than other species, Ceriops tagal was uniquely affected by this activity. Studies thus suggest that the effects of selective cutting on species composition vary according to the characteristics of the species that form the mangrove.

\section{CONCLUSION/CONCLUSÃO}

The results suggest that Laguncularia racemosa is disproportionately affected by selective cutting in relation to the other species, both because of its higher abundance and because it presents the specific diameters sought for the construction of fences and walkways. However, this impact did not alter the dominance or relative density of species in the Guaxindiba River mangrove as a result of the high regeneration of Laguncularia racemosa.

\section{AKNOWLEDGEMENTS}

Thanks are cordially extended to CAPES for the grant offered to Elaine Bernini and for its support for the project AUX-PE-PNPD-2303/2008. Recognition must also go to technicians Gerson R. Purificação and Antônio C. O. Pessanha and to the drivers of UENF for their support in fieldwork, as well as to the Laboratório de Ciências Ambientais for the equipment and infrastructure. CE Rezende was supported by Conselho Nacional de Desenvolvimento Científico e Tecnológico - CNPq (Proc. 304.615/2010-2) and Fundação de Amparo a Pesquisa do Estado do Rio de Janeiro - FAPERJ (Proc. E-26/102.697/2008), respectively. This study was performed in association with the Instituto Nacional de Ciência e Tecnologia - TMCOcean (CNPq Processo 573601/2008-9).

\section{REFERENCES}

ALONGI, D. M. Present state and future of the world's mangrove forests. Environmental Conservation, v. 29, p. 331-349, 2002. 
CHAGAS, G. P.; REZENDE, C. E.; BERNINI, E. The effects of selective cutting on the dominance and the relative density of mangrove species in the Complex of the Guaxindiba River/Engenheiro Antonio Resende Channel, Rio de Janeiro.

ALONGI, D. M.; CARVALHO, N. A. The effect of small-scale logging on stand characteristics and soil biogeochemistry in mangrove forests of Timor Leste. Forest Ecology and Management, v. 255, p. 1359-1366, 2008.

BERGER, U.; ADAMS, M.; GRIMM, V.; HILDENBRANDT, H. Modelling secondary succession of neotropical mangroves: causes and consequences of growth reduction in pioneer species.

Perspectives in Plant Ecology, Evolution and Systematics, p. 7, p. 243-252, 2006.

BERNINI, E.; REZENDE, C. E. Estrutura da vegetação em florestas de mangue do estuário do rio Paraíba do Sul, Estado do Rio de Janeiro, Brasil. Acta Botanica Brasilica, v. 18, p. 491-502, 2004.

BERNINI, E.; REZENDE, C. E. Variação estrutural em florestas de mangue do estuário do rio Itabapoana, ES-RJ. Biotemas, v. 23, p. 49-60, 2010.

BERNINI, E.; REZENDE, C. E. Vegetation structure in a mangrove forest in Southeastern Brazil. Pan American Journal of Aquatic Science, v. 6, n. 3, p. 193-209, 2011.

CINTRON, G.; SCHAEFFER NOVELLI, Y. Methods for studying mangrove structure. In: SNEDAKER, S. C.; SNEDAKER, J. G. (Eds.). The Mangrove Ecosystem: Research Methods. Paris, France: UNESCO, 1984, p. 91-113.

CINTRÓN-MOLERO, G.; SCHAEFFER-NOVELLI, Y. Ecology and management New World mangroves. In: SEELIGER, U. (Ed.). Coastal Plant Communities of Latin America. San Diego: Academic Press, 1992, p. 233-258.

DNAEE. Departamento Nacional de Águas e Energia Elétrica. Projeto Paraíba do Sul: Relatório Principal da Fase B. Ministério de Minas e Energia, Rio de Janeiro, 1993.

EUSEBIO, M. A.; TESORO, F. O.; CABAHUG, D. M. Environmental impact of timber harvesting on mangrove ecosystem in the Philippines. In: National Mangrove Committee (Ed.).

Mangroves of Asia and the Pacific: Status and Management. Quezon City, Philippines: Natural Resources Management Center, Ministry of Natural Resources, 1986. p. 337-354.

EWEL, K. C.; ZHENG, S.; PINZON, Z.; BOURGEOIS, J. A. 1998. Environmental effects of canopy gap formation in high-rainfall mangrove forests. Biotropica, v. 30, p. 510-518, 1998.

GIRI, C.; OCHIENG, E.; TIESZEN, L. L.; ZHU, Z.; SINGH, A.; LOVELAND, T.; MASE, J.; DUKE, $\mathrm{N}$. Status and distribution of mangrove forests of the world using earth observation satellite data. Global Ecology and Biogeography, v. 20, p. 154-159, 2011.

IBGE - Instituto Brasileiro de Geografia Espacial. Geociências. http://www.ibge.gov.br (último acesso 14/06/2008).

OLIVEIRA, A. E. S. Caracterização do Mangue da Praia Gorda, Armação dos Búzios, Estado do Rio de Janeiro - RJ. Revista Científica do Centro Universitário de Barra Mansa, v.9, p. 5156, 2007.

PETRI, D. J. C.; BERNINI, E.; SOUZA, L. M.; REZENDE, C. E. Distribuição das espécies e estrutura do manguezal do rio Benevente, Anchieta, ES. Biota Neotropica, v. 11, p. 1-10, 2011.

PINZON, Z. S., EWEL, K. C. \& PUTZ, F. E.. Gap formation and forest regeneration in a Micronesian mangrove forest. J. Tropic. Ecol., 19:143-153, 2003

QUEIROZ, M. E. F.Análise estrutural de bosques de mangue sob diferentes níveis de corte e caracterização da população de Ucides cordatus (Linnaeus, 1763) presente nestas áreas na vila de Caratateua - Bragança - Pa. Dissertação de Mestrado, Universidade Federal do Pará, Pará, 2009.

SILVA, C. A. R.; LACERDA, L. D.; SILVA, L. F. F.; REZENDE, C. E. Forest structure and biomass distribution in a red mangrove stand in Sepetiba Bay, Rio de Janeiro. Revista Brasileira de Botanica, v. 14, p. 21-25, 1991. 
CHAGAS, G. P.; REZENDE, C. E.; BERNINI, E. The effects of selective cutting on the dominance and the relative density of mangrove species in the Complex of the Guaxindiba River/Engenheiro Antonio Resende Channel, Rio de Janeiro.

SILVA, M. A. B.; BERNINI, E.; CARMO, T. M. S.Características estruturais de bosques de mangue do estuário do rio São Mateus, ES, Brasil. Acta Botanica Brasilica, v. 19, p. 465-471, 2005.

SOARES, M. L. G. Estrutura vegetal e grau de perturbação dos manguezais da Lagoa da Tijuca, Rio de Janeiro, RJ, Brasil. Revista Brasileira de Biologia, v. 59, p. 503-515, 1999.

SOFIATTI, A. Entre a terra e a água: Estudos sobre as relações das sociedades humanas com os manguezais da ecorregião de São Tomé ente 1950 e 2000 . Rio de Janeiro, 2001. 538f. Tese de Doutorado, Universidade Federal Fluminense

SOUZA, M. M. A.; SAMPAIO, E. V. S. B. Variação temporal da estrutura de bosques de mangue de Suape-PE após a construção do Porto. Acta Botanica Brasilica, v. 15, p. 1-12, 2001.

TOMLINSON, P.B. 1986. The botany of mangroves. Cambridge University Press, New York.

VALIELA, I., BOWEN, J. I. \& YORK, J. K. Mangrove forests: one of the world's threatened major tropical environments. BioScience, v. 51, p. 807-815, 2001.

WALTERS, B. B. Ecological effects of small-scale cutting of Philippine mangrove forests. Forest Ecology and Management, v. 206, p. 331-348, 2005.

WALTERS, B. B.; RÖNNBÄCK, P.; KOVACS, J. M.; CRONA, B.; HUSSAIN, S. A.; BADOLA, R.; PRIMAVERA, J.H.; BARBIER, E.; DAHDOUH-GUEBAS, F. Ethnobiology, socio-economics and management of mangrove forests: A review. Aquatic Botany, v, 89, p. 220-236, 2008. 